\title{
Peningkatan Pengetahuan Penggunaan Obat dan Pengenalan Peran Apoteker Dalam Swamedikasi di SMK Kesehatan Pelita
}

\author{
Bangsa Yogyakarta
}

\author{
Nofran Putra Pratama, ${ }^{1,}$ Niken Larasati, ${ }^{2}$ Kurnia Rahayu Purnama Sari ${ }^{3}$, Sugiyono ${ }^{4}$ \\ 1,2,3,4Farmasi, Fkes Universitas Jenderal Achmad Yani, Yogyakarta, Indonesia \\ e-mail: *11nofranputrapratama@gmail.com, mylaraslarashaty@ gmail.com, ${ }^{3}$ \\ kurniarahayupurnamasari@gmail.com, ${ }^{4}$ nano2saras@gmail.com
}

\begin{abstract}
ABSTRAK Peningkatan pembangunan kesehatan menjadi prioritas utama sebagai tolak ukur kemajuan suatu negara. Apoteker adalah salah satu agen tenaga kesehatan yang memiliki peran dalam pembangunan kesehatan, salah satunya dengan melakukan swamedikasi. Kegiatan swamedikasi merupakan suatu tindakan pemilihan obat (tanpa resep dokter) untuk mengatasi penyakit atau gejala penyakit. Poin-poin penting dalam swamedikasi perlu disampaikan kepada masyarakat sehingga dapat terwujud swamedikasi yang aman, rasional, efektif, dan terjangkau. Mengacu pada keterangan di atas maka perlu dilakukan kegiatan pengabdian kepada masyarakat dengan tujuan untuk meningkatkan pengetahuan masyarakat mengenai peran apoteker dalam swamedikasi. Keseluruhan kegiatan terdiri atas empat tahapan yaitu persiapan, pelaksanaan, evaluasi, dan penyelesaian laporan. Tahapan persiapan terdiri dari observasi lapangan, pengumpulan bahan, penyusunan proposal, dan persiapan materi. Tahap pelaksanaan kegiatan yaitu pre test, ceramah, praktik dan diskusi. Tahapan evaluasi meliputi post test, pengisian kuisioner, dan penyusunan laporan. Sasaran kegiatan ini adalah siswa SMK Kesehatan Pelita Bangsa, Desa Ngestiharjo, Kecamatan Kasihan, Kabupaten Bantul, Daerah Istimewa Yogyakarta sebanyak 50 siswa (kelas X). Acara pengabdian kepada masyarakat ini berjalan dengan baik terbukti dengan banyaknya peserta yang aktif bertanya mengenai materi yang disampaikan. Hasil dari kegiatan ini adalah terjadi peningkatan pengetahuan peserta terhadap peran apoteker dalam swamedikasi dari 54,93\% menjadi $84,13 \%$.
\end{abstract}

KATA KUNCI Apoteker; Swamedikasi; Obat.

ABSTRACT Increasing health development is a top priority as a measure of a country's progress. Pharmacists are one of the health agents who have a role in health development, one of which is self-medication. Self-medication activities are acts of drug selection (without a doctor's prescription) to deal with diseases or symptoms of the disease. Important points in self-medication need to be delivered to the community so that safe, rational, effective and affordable self-management can be realized. Referring to the information above, it is necessary to conduct community service activities with the aim of increasing community knowledge about the role of pharmacists in self-medication.

The entire activity consists of four stages, preparation, implementation, evaluation, and completion of the report. The preparation stage consists of field observation, material collection, proposal preparation, and material preparation. The stage of implementation of the activity is the pretest, lecture, practice and discussion. The evaluation stages included the posttest, filling out the 
questionnaire, and preparing the report. The target of this activity is students of SMK Kesehatan Pelita Bangsa, Desa Ngestiharjo, Kecamatan Kasihan, Kabupaten Bantul, Daerah Istimewa Yogyakarta as many as 50 students (class $X)$.

This community service program went well as evidenced by the many participants who actively asked about the material presented. The results of this activity were an increase in participants' knowledge of the role of pharmacists in selfmedication from $54.93 \%$ to $84.13 \%$.

KEYWORDS Pharmacist; Self-medication; Drug.

\section{Pendahuluan}

Apoteker adalah sarjana farmasi yang telah lulus sebagai apoteker dan telah mengucapkan sumpah apoteker (Permenkes RI, 2014). Salah satu kegiatan yang dapat dilakukan oleh apoteker untuk mendukung pembangunan kesehatan adalah penerapan swamedikasi. Swamedikasi atau pengobatan sendiri merupakan kegiatan pemilihan dan penggunaan obat oleh individu untuk mengatasi penyakit atau gejala penyakit. Untuk melakukan swamedikasi secara aman, rasional, efektif dan terjangkau masyarakat perlu menambah bekal pengetahuan dan melatih keterampilan dalam praktik swamedikasi. Ada beberapa pengetahuan minimal yang sebaiknya dipahami masyarakat karena merupakan hal penting dalam swamedikasi, pengetahuan tersebut antara lain tentang mengenali gejala penyakit, memilih produk sesuai dengan indikasi dari penyakit, mengikuti petunjuk yang tertera pada etiket brosur, memantau hasil terapi dan kemungkinan efek samping yang terjadi (Shankar et al., 2002).

Pengobatan sendiri dalam hal ini dibatasi hanya untuk obat-obat modern, yaitu obat bebas dan obat bebas terbatas. Swamedikasi biasanya dilakukan untuk mengatasi keluhan-keluhan dan penyakit ringan, tanpa resep atau intervensi dokter yang banyak dialami masyarakat, antara lain demam, nyeri, batuk, flu, serta berbagai penyakit lain [1]. Tidak bermaksud menjadi pengobat seperti dokter, tetapi apoteker melalui kegiatan swamedikasi diharapkan dapat membimbing masyarakat sehingga masyarakat tahu kapan harus pergi ke dokter. Dalam asuhan kefarmasian, swamedikasi adalah salah satu hal yang harus dilakukan dengan baik untuk mengamankan pasien dari obat dan penyakit sehingga tercapai penggunaan obat yang rasional, meskipun dalam swamedikasi terbatas cakupannya hanya untuk obat bebas dan penyakit ringan.

SMK Kesehatan Pelita Bangsa merupakan sekolah menengah kejuruan dengan akreditasi A yang berfokus pada jurusan farmasi sehingga pengetahuan mengenai swamedekasi perlu ditingkatkan. Pengetahuan mengenai swamedikasi akan menjadi bekal bagi para siswa yang merupakan calon-calon apoteker dimasa depan. 


\section{Metode}

Sasaran kegiatan ini adalah siswa SMK Kesehatan Pelita Bangsa kelas X, Desa Ngestiharjo, Kecamatan Kasihan, Daerah Istimewa Yogyakarta sebanyak 50 siswa. Keseluruhan kegiatan terdiri atas empat tahapan yaitu:

a. Tahap Persiapan

Tahapan persiapan terdiri dari observasi lapangan, pengumpulan bahan, penyusunan proposal, dan persiapan materi.

b. Tahap Pelaksanaan

Tahapan pelaksanaan terdiri dari Pre test, ceramah, diskusi kelompok, dan praktik.

1) Pre test

Peserta dikumpulkan dalam satu ruangan dan diberi soal untuk mengetahui kemampuan siswa terkait swamedikasi sebelum penyampaian materi dan praktik.

2) Ceramah

Adapun materi yang diberikan secara ceramah antara lain: swamedikasi secara umum, poin penting dalam swamedikasi, teknik dan penerapan swamedikasi yang baik serta batasan dalam swamedikasi.

3) Diskusi Kelompok dan Praktik

Peserta akan dibagi menjadi 3 kelompok. Masing-masing kelompok akan dibimbing oleh 1 dosen dan 2 mahasiswa untuk kemudian berdiskusi dan praktik swamedikasi menggunakan beberapa alat peraga yang disediakan, diantaranya: swamedikasi penyakit ringan, penggunaan obat dengan teknik khusus serta pertolongan pertama pada luka

c. Tahap evaluasi

Tahapan evaluasi terdiri dari post test dan pengisian kuisioner

\section{1) Post test}

Peserta diminta mengulang melakukan swamedikasi yang sebelumnya telah dilakukan oleh pemberi materi saat diskusi kelompok, setelah itu akan dilakukan post test untuk mengetahui seberapa jauh pemahaman peserta terhadap materi yang disampaikan.

2) Pengisian Kuisioner

Peserta diminta mengisi kuisioner yang berguna sebagai bentuk evaluasi kegiatan.

d. Tahap akhir

Tahapan ini dilakukan untuk penyelesaian laporan

\section{Hasil}

Data tingkat pengetahuan peserta sebelum dan setelah intervensi atau pemberian materi dapat dilihat pada Gambar 1. Hasil pre test menunjukkan bahwa hanya 9 peserta (18\%) yang memiliki pengetahuan yang baik tentang swamedikasi, sedangkan 37 peserta $(74 \%)$ dan 4 peserta (8\%) masing-masing memiliki kemampuan yang cukup dan kurang. Namun setelah pemberian materi terdapat peningkatan tingkat pengetahuan peserta terkait swamedikasi 
yang dapat dilihat dari nilai post test. Hasil post test menunjukan bahwa 47 peserta (94\%) memiliki pengetahuan yang baik tentang swamedikasi, sedangkan sisanya sejumlah 3 peserta (6\%) memiliki pengetahuan yang cukup.

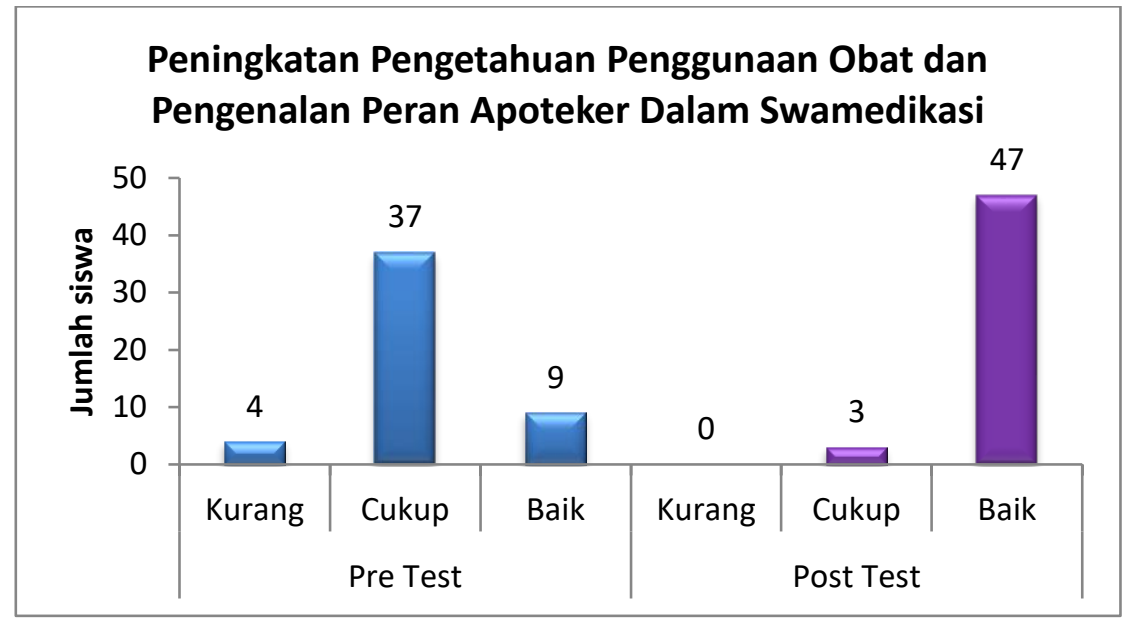

Gambar 1. Tingkat pengetahuan siswa tentang swamedikasi sebelum dan sesudah intervensi.

Adapun nilai yang diperoleh peserta saat pre test dan post test dapat dilihat pada Gambar 2. Nilai rata-rata hasil pretest peserta adalah 54,93 sedangkan nilai rata-rata hasil post test peserta setelah pemberian materi swamedikasi adalah 84,13 .

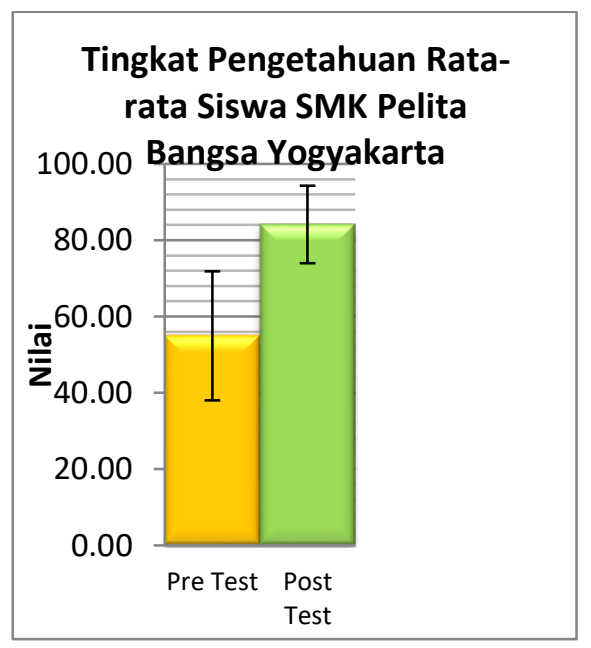

Gambar 2. Tingkat pengetahuan rata-rata siswa SMK Kesehatan Pelita Bangsa Yogyakarta 


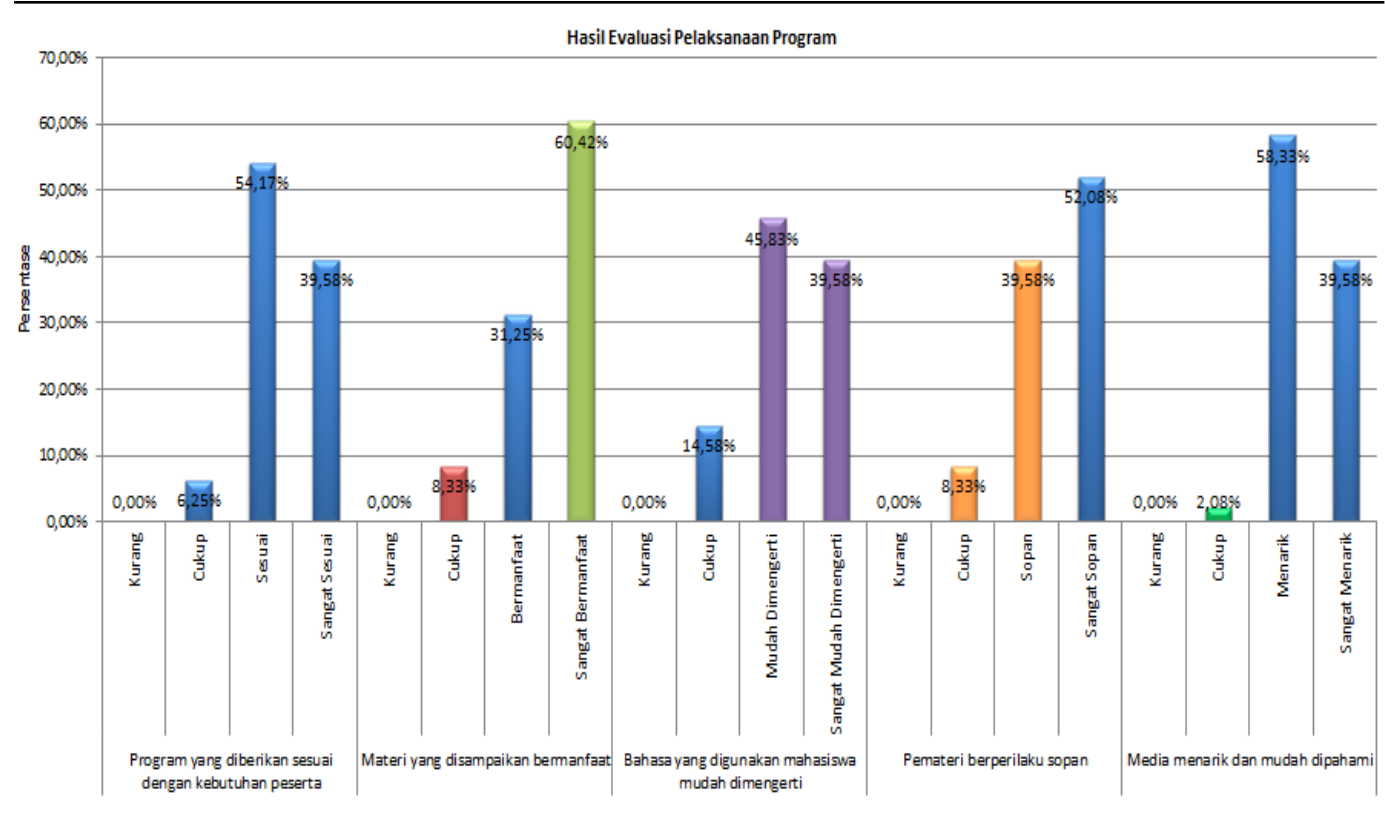

Gambar 3. Hasil evaluasi pelaksanaan program
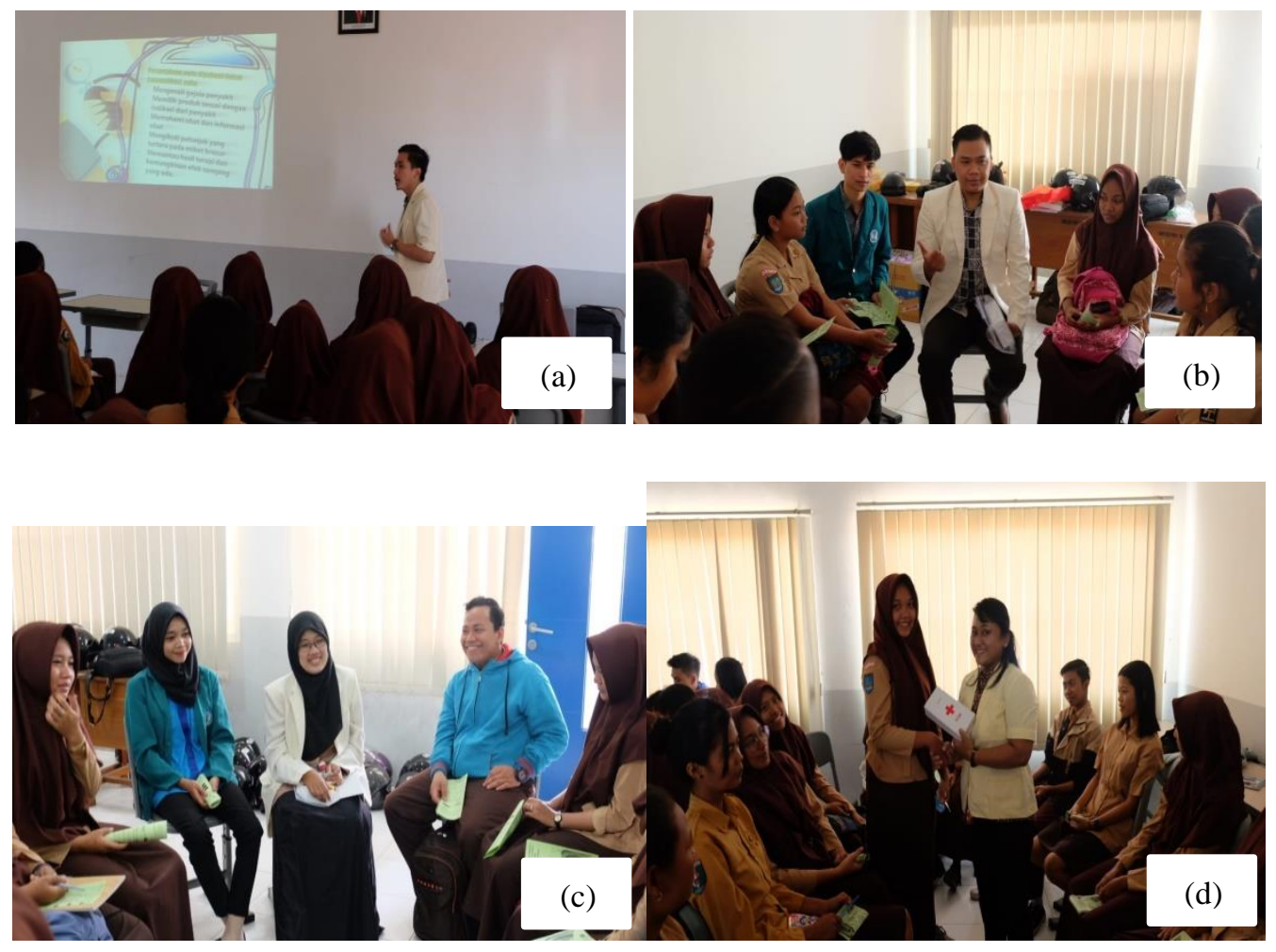

Gambar 4. Penyampaian Materi (a), Praktik swamedikasi dalam kelompok (b), Diskusi kelompok (c), pemberian kenang-kenangan (d)

\section{Pembahasan}

Swamedikasi atau pengobatan sendiri merupakan kegiatan pemilihan dan penggunaan obat oleh individu untuk mengatasi penyakit atau gejala penyakit. Untuk melakukan swamedikasi secara benar, masyarakat memerlukan informasi yang jelas dan dapat dipercaya [2]. Upaya pelatihan swamedikasi pada siswa menunjukan peningkatan terhadap pengetahuan siswa sebelum dan 
sesudah intervensi. Adanya peningkatan nilai ini menunjukkan adanya efek atau pengaruh terhadap pemahaman peserta terhadap swamedikasi.

Tahapan pelaksanaan kegiatan pengabdian kepada masyarakat ini dilaksanakan di ruang kelas SMK Kesehatan Pelita Bangsa Yogyakarta. Kegiatan ini dihadiri oleh siswa kelas $\mathrm{X}$ yang berjumlah 50 orang dan 4 orang berhalangan hadir. Kegiatan dimulai dengan melakukan observasi lokasi dan survei. Metode survei dilakukan dengan wawancara bersama dengan Kepala Sekolah dan beberapa guru terkait tema yang sesuai dengan kebutuhan peserta. Hasil diskusi bersama dengan pihak sekolah diputuskan bahwa tema kegiatan pengabdian kepada masyarakat yang dilakukan adalah Peningkatan Pengetahuan Penggunaan Obat dan Pengenalan Peran Apoteker Dalam Swamedikasi.

Setelah penentuan tema kegiatan dalam pengabdian kepada masyarakat, selanjutnya dilakukan penyusunan program. Metode penyampaian program yang dilakukan adalah dengan komunikasi langsung yaitu ceramah umum dan diskusi kelompok yang disertai dengan praktek. Ceramah umum diberikan sebagai pengantar materi swamedikasi. Selanjutnya peserta dibagi menjadi 3 kelompok kecil dimana masing-masing kelompok akan dibimbing oleh 1 dosen dan 2 mahasiswa untuk kemudian berdiskusi dan praktek swamedikasi menggunakan beberapa alat peraga yang disediakan. Metode ini memiliki keunggulan yaitu dapat memberi informasi secara langsung kepada peserta sehingga peserta yang diberikan penyuluhan akan terfokus perhatiannya kepada pemberi materi. Adapun media yang digunakan dalam kegiatan ini adalah modul yang berisi tentang peran Apoteker dalam swamedikasi yang akan diberikan kepada peserta. Untuk mengetahui peningkatan pengetahuan dari peserta maka dilakukan pretest dan postest berupa soal-soal terkait swamedikasi, sedangkan sebagai bahan evaluasi kegiatan peserta diminta untuk mengisi kuisioner setelah kegiatan selesai dilaksanakan.

Dalam kegiatan pengabdian masyarakat ini para peserta sangat antusias mengikuti kegiatan, karena selama ini banyak peserta yang belum paham mengenai swamedikasi, peran dan batasan Apoteker dalam swamedikasi, dan cara penggunaan obat yang butuh penanganan khusus. Adanya kegiatan pengabdian masyarakat yang telah dilakukan dapat meningkatkan wawasan bagi farmasis remaja dalam swamedikasi.

\section{Kesimpulan}

Bagian Program peningkatan pengetahuan penggunaan obat dan pengenalan peran Apoteker dalam swamedikasi yang diberikan dapat meningkatkan pengetahuan siswa SMK Kesehatan Pelita Bangsa Yogyakarta terhadap swamedikasi. 


\section{Ucapan terima kasih}

Dalam kesempatan ini ucapan terima kasih kami tujukan kepada Kuswanto Hardjo, dr., M.Kes. selaku Dekan Fakultas Kesehatan Universitas Jenderal Achmad Yani Yogyakarta, Deby Zulkarnain, R.S, S.Kep., Ns., MMR. selaku Ketua PPPM Fakultas Kesehatan Universitas Jenderal Achmad Yani Yogyakarta, Kurnia Rahayu Purnomo Sari, M.Sc., Apt. selaku Ketua Program Studi Farmasi (S-1) Universitas Jenderal Achmad Yani Yogyakarta, S. CH. Ari Widiastuti, S.Si., Apt. selaku Kepala Sekolah dan para dewan guru SMK Kesehatan Pelita Bangsa Yogyakarta

\section{Daftar pustaka}

[1] Depkes RI,. Jakarta, Indonesia: Departemen Kesehatan Republik Indonesia, 2006, p. 6.

[2] Depkes RI, Materi Pelatihan Peningkatan Pengetahuan dan Keterampilan Memilih Obat Bagi Tenaga Kesehatan. Jakarta, Indonesia: Departemen Kesehatan Republik Indonesia, 2008. 